\title{
Altered Activity of the System A Amino Acid Transporter in Microvillous Membrane Vesicles from Placentas of Macrosomic Babies Born to Diabetic Women
}

\author{
Ajit G. Kuruvilla, * Stephen W. D’Souza, ` Jocelyn D. Glazier, “ Dhushy Mahendran, „‡ Michael J. Maresh, ${ }^{\ddagger}$ \\ and Colin P. Sibley*\$ \\ Action Research Placental and Perinatal Unit, Departments of ${ }^{*}$ Child Health, ${ }^{\ddagger}$ Obstetrics and Gynaecology, and ${ }^{\S}$ School of Biological \\ Sciences, University of Manchester, St. Mary's Hospital, Manchester M13 OJH, United Kingdom
}

\begin{abstract}
Fetal macrosomia (FM) is a well-recognized complication of diabetic pregnancy but it is not known whether placental transport mechanisms are altered. We therefore studied the activity of the system $A$ amino acid transporter, the system $\mathrm{L}$ amino acid transporter, and the $\mathrm{Na}^{+} / \mathrm{H}^{+}$exchanger in microvillous membrane vesicles from placentas of macrosomic babies born to diabetic women (FM group), from placentas of appropriately grown babies born to diabetic women (appropriate for gestational age group) and from placentas of appropriately grown babies of normal women (control group). Sodium-dependent uptake of $\left[{ }^{14} \mathrm{C}\right]$ methylaminoisobutyric acid at $30 \mathrm{~s}$ (initial rate, a measure of system A activity) was $49 \%$ lower into FM vesicles than into control vesicles $(P<0.02)$; this effect was due to a decrease in $V_{\max }$ of the transporter with no change in $K_{m}$. There was no significant difference in system $A$ activity between the appropriate for gestational age group and control or FM group. There was also no difference between system $\mathrm{L}$ transporter or $\mathrm{Na}^{+} / \mathrm{H}^{+}$exchanger activity between the three groups. We conclude that the number of system $A$ transporters per milligram of membrane protein in the placental microvillous membrane is selectively reduced in diabetic pregnancies associated with FM. (J. Clin. Invest. 1994. 94:689-695.) Key words: placenta - transport proteins • diabetes mellitus $\bullet$ growth disorders $\bullet$ fetus
\end{abstract}

\section{Introduction}

Excessive intrauterine growth leading to a large or macrosomic fetus can have serious perinatal implications $(1,2)$. Where fetal macrosomia (FM) ${ }^{1}$ occurs, the net maternofetal transfer

Preliminary reports of this work were presented to the Society for Gynecologic Investigation Meeting in Toronto on 31 March to 3 April 1993 and to the European Placenta Group Meeting in Manchester on 7-11 September 1993.

Address correspondence to Colin P. Sibley, Ph.D., Department of Child Health, St. Mary's Hospital, Hathersage Road, Manchester M13 0JH, United Kingdom.

Received for publication 15 October 1993 and in revised form 21 April 1994

1. Abbreviations used in this paper: AGA, appropriate for gestational age; EVB, extravesicular buffer; FM, fetal macrosomia; MeAIB, methylaminoisobutyric acid; MVM, microvillous membrane.

J. Clin. Invest.

(C) The American Society for Clinical Investigation, Inc. 0021-9738/94/08/0689/07 $\$ 2.00$

Volume 94, August 1994, 689-695 of nutrients must be increased, but it is not known whether the activity of specific placental transport proteins is altered.

Pregnancy complicated by diabetes mellitus is a well known cause of FM $(3,4)$. The incidence of FM in pregnant diabetic women remains high, despite improvements in their metabolic control, and can complicate up to $40 \%$ of such pregnancies (5). The reasons for excessive fetal growth occurring in these pregnancies are not known. Pedersen (6) suggested that maternal hyperglycemia leads to fetal hyperglycemia and hence fetal hyperinsulinemia, which may then stimulate excessive intrauterine growth. However, it is well known that some diabetic women give birth to macrosomic babies despite satisfactory glycemic control during their pregnancy (7). The Pedersen hypothesis was later expanded to include other metabolic fuels including amino acids (8). Amino acids are important to the fetus, both as building blocks for tissue accretion and as a source of fuel for fetal oxidative catabolism (9). However, the activity of amino acid transporters, or indeed of other transporters, in placentas of diabetic women with macrosomic babies has not been investigated.

The transcellular movement of amino acids across the syncytiotrophoblast, the main exchange barrier of the placenta, is mediated by specific transporters present on both the maternal facing microvillous plasma membrane (MVM) and the fetal facing basal plasma membrane (10). The $\mathrm{Na}^{+}$-dependent system A transporter, present on both syncytiotrophoblast membranes, mediates the transport of neutral amino acids with short, polar, linear side chains. Its activity in the MVM is reduced by $50-60 \%$ in pregnancies associated with intrauterine growth retardation $(11,12)$. The primary aim of this study was therefore to investigate whether the activity of this transporter is also altered in cases of FM arising from pregnancies complicated by maternal diabetes. Vesicles prepared from the MVM were used, and for comparison the activity of the $\mathrm{Na}^{+}$-independent system $L$ amino acid transporter was also investigated.

The human placental syncytiotrophoblast has been shown to possess $\mathrm{Na}^{+} / \mathrm{H}^{+}$exchanger activity, with that on the MVM resembling the NHE-1 isoform, whereas the basal membrane exchanger resembles the NHE-2 isoform (13). The NHE-1 isoform is postulated to be associated with "housekeeping" functions such as cellular $\mathrm{pH}$ regulation (13). The second aim of this study was therefore to determine whether there were any changes in $\mathrm{MVM} \mathrm{Na}{ }^{+} / \mathrm{H}^{+}$exchanger activity in diabetic pregnancies associated with FM, a clinical situation where the metabolic requirements of both fetus and trophoblast are likely to be altered.

To separate effects of diabetes alone from those due to macrosomia, placentas from diabetic and nondiabetic women giving birth to appropriately grown babies were studied in addition to those from diabetic women giving birth to macrosomic babies. 


\section{Methods}

\section{Patient selection}

This study was approved by the Central Manchester Health Authority Ethical Committee. Placentas from three groups of patients were studied. One group was a control group of women who had normal pregnancies and for whom there was no evidence to suggest undiagnosed diabetes. The birth weights in this group ranged between the 3rd and 90th centiles (14). These women either had spontaneous vaginal deliveries $(n=11)$ or elective caesarean sections because of breech presentation or previous caesarean section $(n=7)$ and were chosen to allow study of a control vesicle preparation within 1-2 wk of that of a diabetic patient. A second group consisted of women with diabetes or impaired glucose tolerance (see below) giving birth, by vaginal delivery $(n=7)$, or elective ( $n$ $=4)$ or emergency $(n=1)$ caesarean section, to babies of normal birth weight (appropriate for gestational age [AGA] group). The birth weights in this group ranged between the 10th and 97th centiles. Five of these women had type 1 diabetes (three Hare and White [15] class B, two class C), five had impaired glucose tolerance (16), and two had gestational diabetes (16). The third group consisted of women with diabetes or impaired glucose tolerance giving birth, by spontaneous vaginal delivery $(n=5)$ or elective $(n=6)$ or emergency $(n=2)$ caesarean section, to macrosomic babies defined as having birth weights above the 97th centile (FM group). Seven of these women had type 1 diabetes (one class A, one class B, four class $C$, one class $D$ ), and six had impaired glucose tolerance. The estimated date of delivery in all three groups was determined from the last menstrual period and was confirmed by ultrasound scan performed at 16-18 wk, and all babies were in a good condition at birth.

All the women with diabetes attended the combined obstetric/medical antenatal clinic for diabetic patients at St. Mary's Hospital and performed self-monitoring of blood glucose, normally measuring their capillary glucose concentrations four times daily, and glycated hemoglobin (hemoglobin $A_{1 c}$ ) concentrations were measured every 4 wk. Women with gestational impaired glucose tolerance or diabetes were managed using dietary measures and insulin treatment was commenced only if capillary glucose concentrations persistently exceeded $6 \mathrm{mmol} /$ liter. In the AGA group, 11 women received insulin, and 8 received insulin in the FM group. For most patients in AGA and FM groups, pregnancy was terminated at or near term (by amniotomy and oxytocin infusion or by caesarean section) because of obstetric or medical indications (such as previous caesarean section, evolving fetal overgrowth, and inadequate glycemic control); only one patient was allowed to pass $40 \mathrm{wk}$, labor being subsequently induced at $41 \mathrm{wk}$.

\section{Vesicle preparation}

Placentas were collected within 30 min of delivery. MVM vesicles were prepared using a homogenization and $\mathrm{Mg}^{2+}$ precipitation technique exactly as described previously $(12,17)$. Vesicle suspensions were stored at $4^{\circ} \mathrm{C}$, and all uptake measurements were performed within 48 $h$ of vesicle preparation.

Protein estimation was performed according to the method of Lowry et al. (18) using bovine serum albumin as standard. Alkaline phosphatase activity, a marker of the MVM (19), was measured, at pH 9.8, using $p$-nitrophenyl phosphate as a substrate (20). The vesicles were also checked for contamination with intracellular organelles by assaying for succinate dehydrogenase and NADH dehydrogenase activities as mitochondrial and endoplasmic reticulum markers, respectively (21, 22). The orientation of the vesicles was investigated by measuring alkaline phosphatase specific activity before and after permeabilizing the vesicles with $0.1 \%$ saponin (17).

\section{Uptake methods}

$\left[{ }^{14} \mathrm{C}\right] \mathrm{MeAIB}$ uptake. The activity of the system $\mathrm{A}$ amino acid transporter in MVM vesicles was determined as described previously (12) by measuring the room temperature uptake by the vesicles at various times of $\left[{ }^{14} \mathrm{C}\right]$ methylaminoisobutyric acid $\left(\left[{ }^{14} \mathrm{C}\right] \mathrm{MeAIB}\right.$; Amersham, Aylesbury, Bucks, UK), a nonmetabolizable amino acid analogue specific for this system (23), in the presence of either an inwardly directed $\mathrm{Na}^{+}$gradient or an inwardly directed $\mathrm{K}^{+}$gradient. The activity of the transporter, per milligram of membrane protein, was defined as the difference in initial rate uptake between that in the presence of $\mathrm{Na}^{+}$and that in the presence of $\mathrm{K}^{+}$(i.e., $\mathrm{Na}^{+}$-dependent uptake). Intravesicular $\left[{ }^{14} \mathrm{C}\right] \mathrm{MeAIB}$ was separated from extravesicular $\left[{ }^{14} \mathrm{C}\right]$ MeAIB using vacuum filtration with millipore filters, and binding of $\left[{ }^{14} \mathrm{C}\right] \mathrm{MeAIB}$ to vesicle membranes was separately quantified by incubating vesicles in the presence of $0.2 \%$ Triton and determining uptake at $2 \mathrm{~h}(12)$. Nonspecific binding of radiolabel to the filters was determined by omitting vesicle protein from some incubations and was corrected for in the calculation of vesicle uptake. All determinations were performed in duplicate. Once initial rate and equilibrium were established, full time courses of uptake were not performed.

The Michaelis-Menten constants $V_{\max }$ and $K_{\mathrm{m}}$ for the transporter were measured in four preparations of control group MVM vesicles and four preparations of FM group vesicles. As described previously (12), uptake of $\left[{ }^{14} \mathrm{C}\right] \mathrm{MeAIB}$ was measured at $30 \mathrm{~s}$ (initial rate; see Results) in the presence and absence of $\mathrm{Na}^{+}$and at increasing total concentrations of MeAIB from 0.16 to $20.17 \mathrm{mM}$, achieved by adding appropriate amounts of nonradioactive MeAIB to the extravesicular buffer (EVB). $\mathrm{Na}^{+}$-dependent MeAIB uptake per milligram of membrane protein was plotted against MeAIB concentration, and the data were fitted to the Michaelis-Menten equation by nonlinear regression (P-Fit; Biosoft, Cambridge, UK).

$\left[{ }^{14} \mathrm{C}\right]$ Leucine uptake. The activity of the MVM system $\mathrm{L}$ amino acid transporter, which is $\mathrm{Na}^{+}$independent $(23,24)$, was determined by measuring the uptake into MVM vesicles of $\left[{ }^{14} \mathrm{C}\right]$ leucine, an amino acid which is transported primarily by this system $(10,23)$, using a method similar to that described by Kudo and colleagues (23) and buffers as similar as possible to those used for measuring $\left[{ }^{14} \mathrm{C}\right] \mathrm{MeAIB}$ uptake (12), omitting $\mathrm{Na}^{+}$from the EVB. MVM vesicles were suspended in buffer A ( $290 \mathrm{mM}$ sucrose, $5 \mathrm{mM}$ Hepes, $5 \mathrm{mM}$ Tris; titrated to $\mathrm{pH} 7.4$ with $11.6 \mathrm{M} \mathrm{HCl}$ ) at a protein concentration of $20-25 \mathrm{mg}$ / $\mathrm{ml}$, and uptake reactions were initiated by mixing $20 \mu \mathrm{l}$ vesicle suspension with $20 \mu$ l buffer B ( $145 \mathrm{mM} \mathrm{KCl,} 5 \mathrm{mM}$ Hepes, $5 \mathrm{mM}$ Tris; titrated to $\mathrm{pH} 7.4$ with $11.6 \mathrm{M} \mathrm{HCl}$ after which $50 \mu \mathrm{Ci} / \mathrm{ml}\left[\mathrm{L}-{ }^{14} \mathrm{C}\right]$ leucine [Amersham] was added) so that the final concentration of $\left[{ }^{14} \mathrm{C}\right]$ leucine was $20 \mu \mathrm{M}$. In each experiment, $\left[{ }^{14} \mathrm{C}\right]$ leucine uptake was also measured in the presence of a vast excess of nonradioactive $\mathrm{L}$-leucine to determine that proportion of uptake not mediated by a transporter; $20 \mu \mathrm{l}$ vesicle protein was mixed with $20 \mu \mathrm{l}$ buffer $\mathrm{C}(240 \mathrm{mM}$ sucrose, $50 \mathrm{mM}$ leucine, $5 \mathrm{mM}$ Hepes, $5 \mathrm{mM}$ Tris; titrated to $\mathrm{pH} 7.4$ with $11.6 \mathrm{M} \mathrm{HCl}$ and to which $\left[\mathrm{L}-{ }^{14} \mathrm{C}\right]$ leucine was added so that the final radioactive leucine concentration was $20 \mu \mathrm{M}$ ). In preliminary experiments we found uptake of $\left[{ }^{14} \mathrm{C}\right]$ leucine at room temperature to be too rapid to determine initial rate activity, and all uptakes reported here were performed at $4^{\circ} \mathrm{C}$. Reactions were terminated at the appropriate times by addition of $2 \mathrm{ml}$ ice-cold Krebs-Ringer phosphate solution ( $130 \mathrm{mM} \mathrm{NaCl}, 10 \mathrm{mM}$ $\mathrm{Na}_{2} \mathrm{HPO}_{4}, 4.2 \mathrm{mM} \mathrm{KCl}, 1.2 \mathrm{mM} \mathrm{MgSO}{ }_{4}, 0.75 \mathrm{mM} \mathrm{CaCl}_{2}$; titrated to pH 7.4 with $11.6 \mathrm{M} \mathrm{HCl}) .1 \mathrm{ml}$ of this suspension was applied immediately to a millipore filter (presoaked in ice-cold Krebs-Ringer phosphate) and washed with $10 \mathrm{ml}$ ice-cold Krebs-Ringer phosphate. Filters were placed in glass vials to which $2 \mathrm{ml}$ 2-ethoxyethanol and $12 \mathrm{ml}$ Optiphase "HiSafe II" liquid scintillation fluid (Pharmacia, Milton Keynes, UK) were added and counted in a liquid scintillation analyzer (model 2000CA; Packard, Pangbourne, Berks, UK), as for [ $\left.{ }^{14} \mathrm{C}\right] \mathrm{MeAIB}$ uptake measurements (12). Binding of $\left[\mathrm{L}-{ }^{14} \mathrm{C}\right]$ leucine to the membranes was measured in the presence of $0.2 \%$ Triton, and nonspecific binding to the filters was measured and corrected for as with $\left[{ }^{14} \mathrm{C}\right]-$ MeAIB uptake measurements.

Sodium uptake. Sodium uptake into MVM vesicles was measured at room temperature using ${ }^{22} \mathrm{NaCl}$ (Amersham) in the presence of an outwardly directed $\mathrm{H}^{+}$gradient and either with or without the presence of $0.5 \mathrm{mM}$ amiloride in the EVB as described previously $(12,17)$. The activity of the $\mathrm{Na}^{+} / \mathrm{H}^{+}$exchanger was defined as the amiloride inhibitable component. Ion-exchange columns were used to separate extravesicular sodium-22, retained by the resin from intravesicular sodium-22, which was collected as the eluent $(17,25)$. Radiolabel not 
Table I. Clinical Details of Groups

\begin{tabular}{lccc}
\hline & Control & AGA & FM \\
\hline$n$ & 18 & 12 & 13 \\
Age $(y r)$ & $26 \pm 1$ & $28 \pm 2$ & $30 \pm 2$ \\
Parity & $1.3 \pm 0.3$ & $1.3 \pm 0.4$ & $2.5 \pm 1.0$ \\
Gestation $(d)$ & $276 \pm 2$ & $272 \pm 2$ & $268 \pm 2^{*}$ \\
Birth weight $(k g)$ & $3.3 \pm 0.1$ & $3.5 \pm 0.1$ & $4.4 \pm 0.1^{\ddagger}$ \\
Placental weight $^{8}(g)$ & $559 \pm 25$ & $568 \pm 52$ & $671 \pm 28^{*}$ \\
& & & \\
\hline
\end{tabular}

Values are mean $\pm S E$ in control, AGA diabetic, and FM diabetic groups. Numbers in each group are as indicated, except for ${ }^{8}$ placental weights where $n=12,5$, and 11 for control, AGA, and FM groups, respectively; this lower number of determinations reflects deliveries later in the study when systematically the umbilical cord was divided at the point of insertion, blood clots were removed, and the placenta was dry blotted. ${ }^{*} P<0.05$ compared with control group; ${ }^{\ddagger} P<0.001$ compared with control and AGA groups; ANOVA with Scheffe.

retained by the columns was corrected for by replacing vesicle protein with intravesicular buffer. To identify membrane-bound as opposed to intravesicular sodium-22, some incubations were carried out in the presence of $0.2 \%$ Triton. As for $\left[{ }^{14} \mathrm{C}\right] \mathrm{MeAIB}$ uptake, once initial rate and equilibrium were established, full time courses of uptake were not performed. To ensure that the percentage of vesicles recovered from the columns did not differ between the groups, alkaline phosphatase specific activity of the eluents was measured in separate experiments where sodium-22 was omitted from the initial reaction mix and compared with that of the vesicles applied to the columns.

\section{Statistics}

Data are presented as mean $\pm \mathrm{SE}$, and statistical comparisons were made using ANOVA followed by Scheffe's multiple comparisons procedure or Student's unpaired $t$ test as appropriate, $n$ being the number of placentas.

\section{Results}

Clinical characteristics of groups. Some clinical details of the three groups are compared in Table I. As expected, birth weights in the FM group were significantly higher than those in control and AGA groups. Placental weights were significantly higher in the FM as compared with the control group. Gestational age at delivery was significantly lower in the FM as compared with the control group, reflecting our practice of expediting delivery when excessive fetal growth was suspected or if metabolic control had been judged inadequate. There was no significant difference between the AGA and FM groups in regard to metabolic control at any stage of gestation; for example, at term, plasma glucose concentration in the AGA and FM groups was $6.3 \pm 0.3$ and $6.2 \pm 0.2 \mathrm{mmol} /$ liter, respectively, and hemoglobin $\mathrm{A}_{1 \mathrm{c}}$ was identical in the two groups at $6.5 \pm 0.3 \%$ (the upper limit of normal for our laboratory being $7 \%$ ).

Vesicle characteristics. Enzyme enrichments relative to the starting placental homogenate, vesicle orientation, and vesicle protein recovery are shown in Table II. All three sets of vesicles were highly enriched in alkaline phosphatase activity; the enrichment of the AGA group was slightly, but significantly, lower than that of the control group but was not different from the FM group, nor was there a difference between the FM and control groups. None of the sets of vesicles were enriched in succinate dehydrogenase or NADH dehydrogenase activity. In addition, vesicle orientation in the three groups was very simi-
Table II. Enzyme Enrichments, Vesicle Orientation, and Vesicle Protein Recovery

\begin{tabular}{lccc}
\hline & Control & AGA & FM \\
\hline ALK* & $22 \pm 1(18)$ & $18 \pm 1^{\ddagger}(12)$ & $20 \pm 1(13)$ \\
NADH $^{*}$ & $0.39 \pm 0.17(4)$ & $0.32 \pm 0.09(5)$ & $0.31 \pm 0.11(4)$ \\
SDH $^{*}$ & $0.54 \pm 0.24(3)$ & $0.45 \pm 0.17(5)$ & $0.04 \pm 0.03(5)$ \\
VO $^{8}$ & $99 \pm 1(10)$ & $98 \pm 1(8)$ & $98 \pm 1(6)$ \\
VPR $^{1}$ & $0.23 \pm 0.01(17)$ & $0.26 \pm 0.03(7)$ & $0.24 \pm 0.01(13)$
\end{tabular}

Values are mean $\pm \operatorname{SE}(n) . \quad *$ Enzyme enrichments are calculated as vesicle enzyme specific activity relative to that for the starting placental homogenate and are given for alkaline phosphatase $(A L K)$, NADH dehydrogenase $(N A D H)$, and succinate dehydrogenase $(S D H) .{ }^{8} \mathrm{VO}$, vesicle orientation calculated as the ratio of vesicle alkaline phosphatase activity before and after addition of $1 \%$ saponin. ' $V P R$, vesicle protein recovery calculated as milligrams of MVM protein obtained per gram of starting wet placental tissue. ${ }^{\ddagger} P<0.05$ ANOVA with Scheffe as compared with control group.

lar, as was vesicle protein recovery. These data indicate that there was little difference between the three groups of vesicles in terms of their basic characteristics.

$\left[{ }^{14} \mathrm{C}\right] \mathrm{MeAIB}$ uptake by vesicles. The time courses of $\left[{ }^{14} \mathrm{C}\right]-$ MeAIB uptake by the vesicles are shown in Fig. 1. As found previously (12), uptake was initially rapid, but equilibrium was not finally achieved until $20-24 \mathrm{~h}$, as reflected by the similarity in uptakes at 20 and $24 \mathrm{~h}$ (data not shown). Binding of $\left[{ }^{14} \mathrm{C}\right]-$ MeAIB to the membranes, as measured after incubating the vesicles in the presence of triton, was $<2 \%$ of equilibrium uptake in all three groups (Fig. 1). There was a significant difference between uptake in the presence of an $\mathrm{Na}^{+}$gradient to that in $\mathrm{a} \mathrm{K}^{+}$gradient at all time points up to $120 \mathrm{~min}$. The uptakes were linear over the first minute of the reaction so that, for comparison purposes, measurements at $30 \mathrm{~s}$ were taken to represent the initial rate. As shown in Table III, the initial uptake by the FM vesicles in the presence of an $\mathrm{Na}^{+}$gradient, but not that in the presence of a $\mathrm{K}^{+}$gradient, was significantly lower than that into the control vesicles. Consequently, the calculated initial rate of uptake due to the $\mathrm{Na}^{+}$-dependent system A transporter (the difference between that in the presence of an $\mathrm{Na}^{+}$ gradient and that in the presence of a $\mathrm{K}^{+}$gradient) was $49 \%$ lower in the FM than in the control vesicles (Table III). Initial uptakes of $\left[{ }^{14} \mathrm{C}\right] \mathrm{MeAIB}$ by the AGA vesicles were not significantly different from those by the control or FM vesicles. Equilibrium $(24 \mathrm{~h})$ uptakes were not significantly different between any of the three groups $(0.587 \pm 0.097 \mathrm{nmol} / \mathrm{mg}$ protein, $n=10$; $0.483 \pm 0.185 \mathrm{nmol} / \mathrm{mg}$ protein, $n=3 ; 0.653 \pm 0.110 \mathrm{nmol} / \mathrm{mg}$ protein, $n=9$; control, AGA, and FM groups, respectively).

As control and FM groups showed a significant difference in system A transporter activity, transporter kinetics were compared between these two groups. Initial rate of $\mathrm{Na}^{+}$-dependent MeAIB uptake in four preparations each of control and FM vesicles is plotted against MeAIB concentration in Fig. 2. $V_{\max }$, calculated from these plots, was significantly $(P<0.02)$ lower in the FM group as compared with the control group $(0.47 \pm 0.07$ vs $0.96 \pm 0.13 \mathrm{nmol} / \mathrm{mg}$ protein per $30 \mathrm{~s}$, respectively), but there was no significant difference in $K_{\mathrm{m}}(2.10 \pm 1.08$ vs $1.44 \pm 0.80$ $\mathrm{mM}$, respectively).

$\left[{ }^{14} \mathrm{C}\right]$ Leucine uptake by vesicles. The early time course of $\left[{ }^{14} \mathrm{C}\right]$ leucine uptake by the three groups of vesicles is shown in Fig. 3. As can be seen, despite measurements being made at 

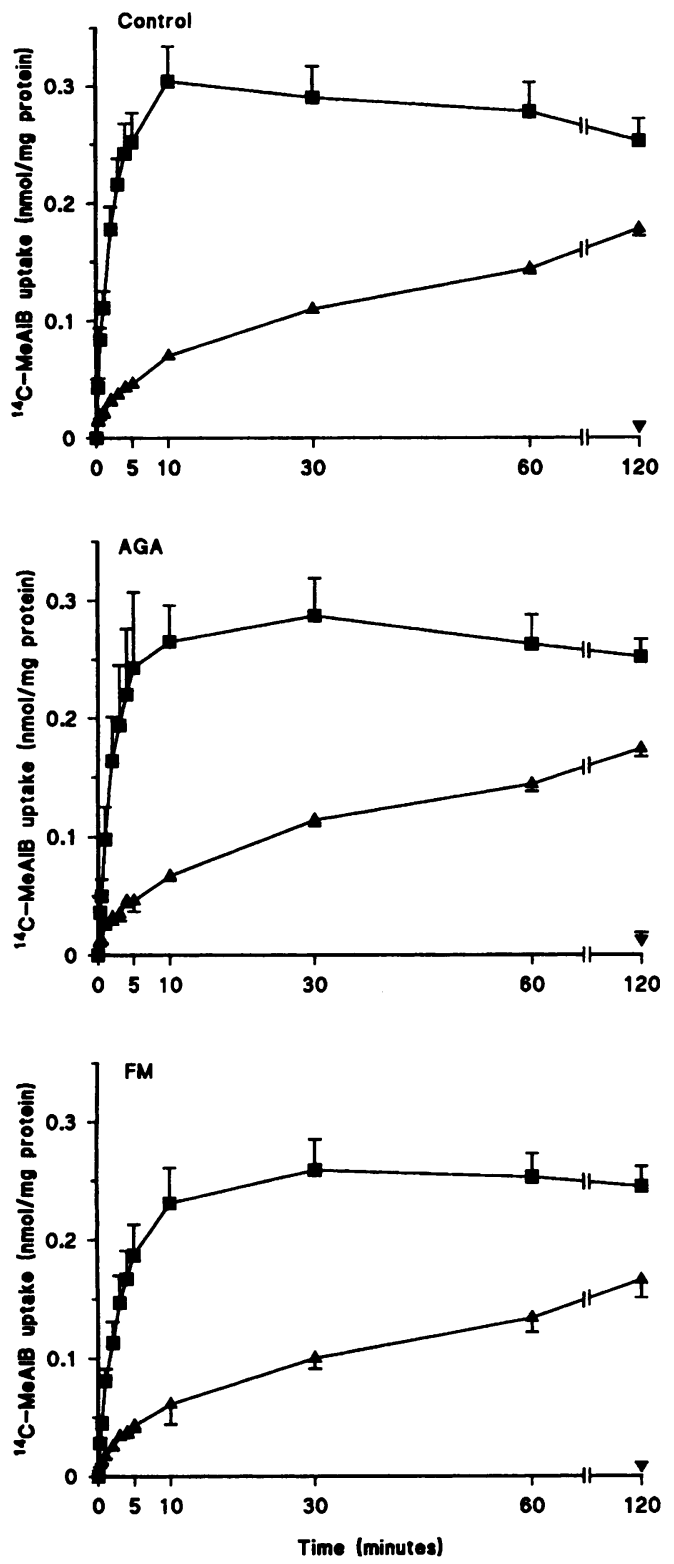

Figure 1. Time course of $\left[{ }^{14} \mathrm{C}\right] \mathrm{MeAIB}$ uptake by control, AGA, and FM vesicles. Vesicles were suspended in buffer consisting of $290 \mathrm{mM}$ sucrose, $5 \mathrm{mM}$ Hepes, and $5 \mathrm{mM}$ Tris- $\mathrm{HCl}, \mathrm{pH} \mathrm{7.4,} \mathrm{at} \mathrm{a} \mathrm{concentration}$ of $\sim 15 \mathrm{mg} / \mathrm{ml}$. Uptakes were initiated at room temperature by adding $20 \mu \mathrm{l}$ of vesicle suspension to $20 \mu \mathrm{l}$ of EVB consisting of $145 \mathrm{mM}$ $\mathrm{NaCl}$ (匹) (or $\mathrm{KCl}, \Delta$ ), $5 \mathrm{mM}$ Hepes, $5 \mathrm{mM}$ Tris-HCl, pH 7.4, to which $15.7 \mu \mathrm{Ci} / \mathrm{ml}\left[{ }^{14} \mathrm{C}\right] \mathrm{MeAIB}$ had been added, with the final concentration of $\left[{ }^{14} \mathrm{C}\right] \mathrm{MeAIB}$ in the reaction being $0.165 \mathrm{mM}$. The reaction was terminated at the intervals shown by adding $2 \mathrm{ml}$ of ice-cold KrebsRinger phosphate solution. $1 \mathrm{ml}$ was filtered immediately through presoaked millipore filters $(0.45 \mu \mathrm{m})$ and washed with $10 \mathrm{ml}$ of KrebsRinger phosphate solution. $\nabla$ represents uptake in the presence of $0.2 \%$ Triton. Values shown are mean $\pm S E$ for vesicle preparations from 9 to 15 placentas in the control group, 3 to 6 placentas in the AGA group, and 7 to 13 placentas in the FM group. Error bars are not shown if smaller than the symbol size.

$4^{\circ} \mathrm{C}$, uptake appeared to start to plateau at $5 \mathrm{~s}$, but this was similar for all three groups. $\left[{ }^{14} \mathrm{C}\right]$ Leucine uptake in the presence of excess unlabeled leucine was $<10 \%$ of total uptake (Fig. 3 and Table IV), suggesting that the majority of uptake was via
Table III. Initial (30 s) Uptakes of $\left[{ }^{14} \mathrm{C}\right] \mathrm{MeAIB}$ by Vesicles

\begin{tabular}{lccc}
\hline & \multicolumn{3}{c}{$\left[{ }^{14} \mathrm{C}\right]$ MeAIB uptake } \\
\cline { 2 - 4 } & \multicolumn{4}{c}{$\mathrm{K}^{+}$} & "A" \\
\hline \multicolumn{4}{c}{ nmolmg protein per $30 \mathrm{~s}$} \\
Control (15) & $0.084 \pm 0.010$ & $0.019 \pm 0.003$ & $0.065 \pm 0.009$ \\
AGA (6) & $0.050 \pm 0.014$ & $0.012 \pm 0.002$ & $0.038 \pm 0.013$ \\
FM (13) & $0.045 \pm 0.005^{*}$ & $0.012 \pm 0.001$ & $0.033 \pm 0.004^{\ddagger}$
\end{tabular}

Values are mean $\pm \mathrm{SE}(n)$. Uptakes are shown for $\mathrm{Na}^{+}$and $\mathrm{K}^{+}$gradients and also for that due specifically to the system $\mathrm{A}$ transporter (" $A$ "), calculated as the difference between the former two. ${ }^{*} P<0.01 ;{ }^{\ddagger} P$ $<0.02$ compared with control group; ANOVA with Scheffe.

the system $\mathrm{L}$ transporter. Binding of $\left[{ }^{14} \mathrm{C}\right]$ leucine to the membranes, as measured in the presence of triton, was $<7 \%$ of equilibrium uptake in all three groups. 3-s uptake was taken as giving an approximation of initial rate, and these data are shown in Table IV for total, nonmediated (excess unlabeled leucine), and system $L$ (the difference between total and nonmediated) mediated uptake. There was no difference in any of these variables between the three groups. Equilibrium ( $24 \mathrm{~h}$; there was no difference in uptake between 2- and 24-h measurements) uptake was also not different between the three groups.

$\mathrm{Na}^{+}$uptake by vesicles. The percentage of vesicles recovered in the eluent from the ion-exchange columns was similar in control $(46 \pm 2 \%, n=9)$, AGA $(52 \pm 3 \%, n=7)$, and FM $(48 \pm 2 \%, n=7)$ groups.

The time courses for $\mathrm{Na}^{+}$uptake by the vesicles are shown in Fig. 4. As found previously $(12,17)$ in the absence of amiloride, $\mathrm{Na}^{+}$uptake is initially rapid and is accompanied by an overshoot at 5-10 min. This is followed by an efflux of $\mathrm{Na}^{+}$, and equilibrium is reached by $2 \mathrm{~h}$, as reflected by the similarity in uptakes at 2 and $24 \mathrm{~h}$ (data not shown). Binding of sodium22 to the membranes, as measured in the presence of triton,

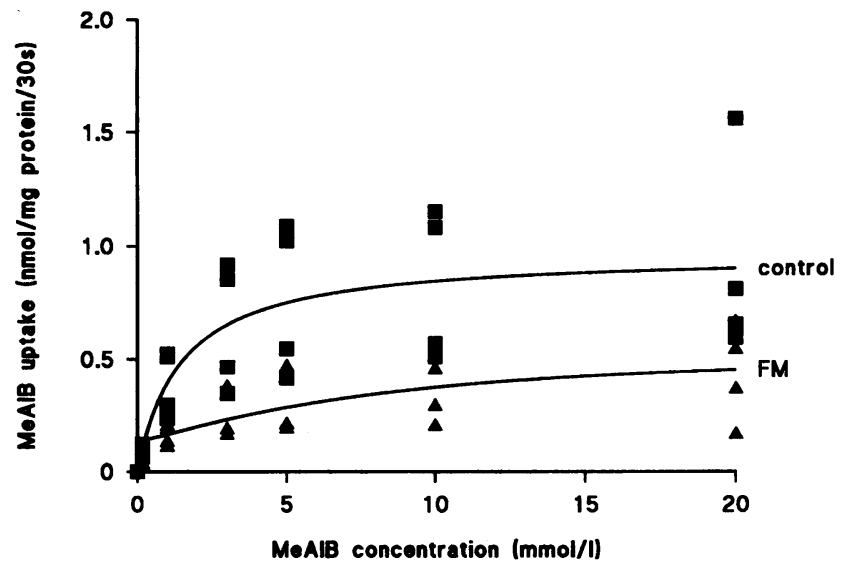

Figure 2. Kinetics of MeAIB uptake by control ( $\square)$ and FM ( $\Delta$ ) vesicles. Initial rate (30 s) uptake of MeAIB in the presence and absence of $\mathrm{Na}^{+}$ was measured, as in Fig. 1, over a range of MeAIB concentrations in the EVB. Data were obtained from four placentas each in the two groups shown. $\mathrm{Na}^{+}$-dependent uptake (the difference between that in the presence and that in the absence of $\mathrm{Na}^{+}$) has been plotted, as individual data points (one at each concentration from each placenta) against MeAIB concentration, and the data were fitted by nonlinear regression to the Michaelis-Menten equation to allow calculation of $V_{\max }$ and $K_{\mathrm{m}}$. 

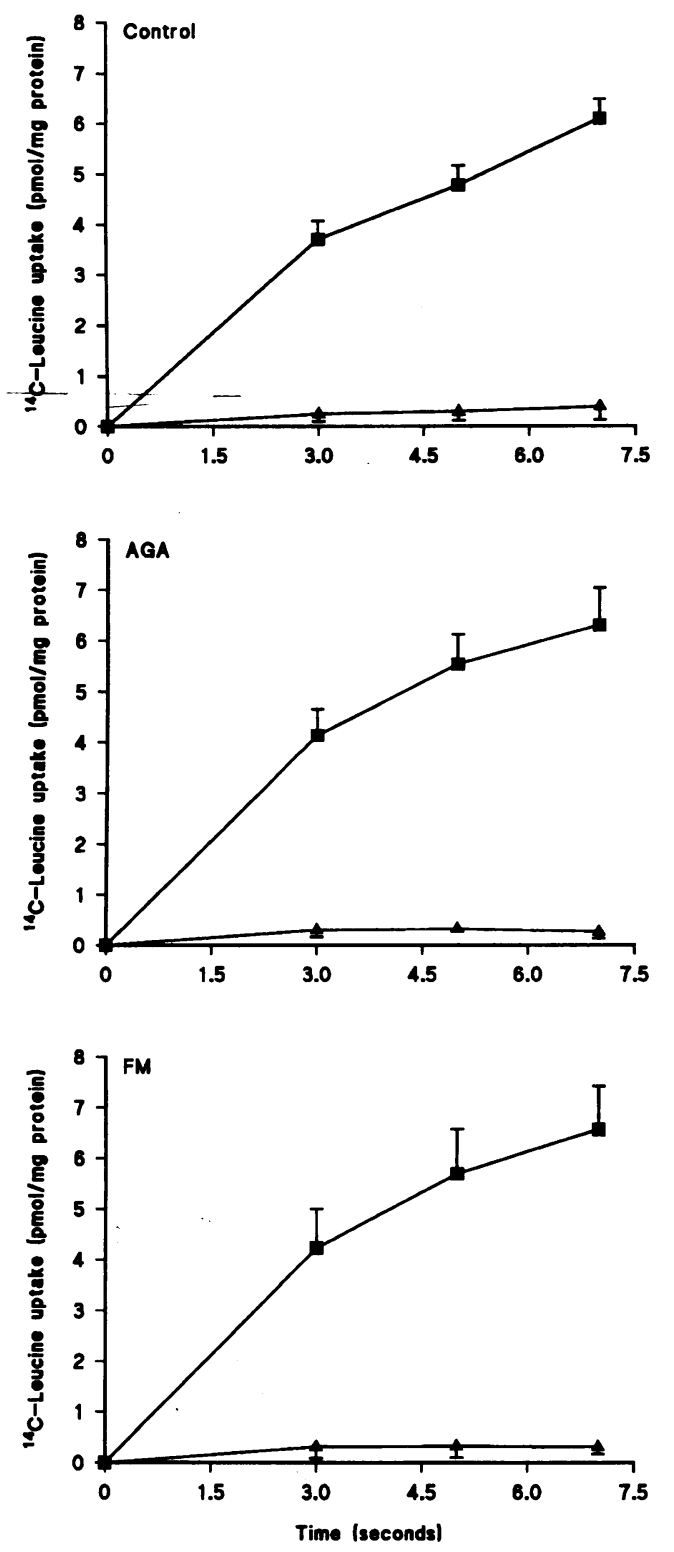

Figure 3. Early time course of $\left[{ }^{14} \mathrm{C}\right]$ leucine uptake by control, AGA, and $\mathrm{FM}$ vesicles measured at $4^{\circ} \mathrm{C}$. Vesicles were suspended in buffer A, consisting of $290 \mathrm{mM}$ sucrose, $5 \mathrm{mM}$ Hepes, $5 \mathrm{mM}$ Tris- $\mathrm{HCl}$, $\mathrm{pH} 7.4$, at a protein concentration of $20-25 \mathrm{mg} / \mathrm{ml}$, and uptake reactions were initiated by mixing $20 \mu \mathrm{l}$ vesicle suspension with 20 $\mu \mathrm{l}$ of buffer B consisting of $145 \mathrm{mM} \mathrm{KCl}, 5 \mathrm{mM}$ Hepes, $5 \mathrm{mM}$ Tris; titrated to $\mathrm{pH} 7.4$ with $11.6 \mathrm{M} \mathrm{HCl}$ after which $50 \mu \mathrm{Ci} / \mathrm{ml}$ [L$\left.{ }^{14} \mathrm{C}\right]$ leucine was added so that the final concentration of $\left[{ }^{14} \mathrm{C}\right]-$ leucine was $20 \mu \mathrm{M}$. $\left[{ }^{14} \mathrm{C}\right]$ Leucine uptake was also measured in the presence of a vast excess of nonradioactive L-leucine to determine that proportion of uptake not mediated by a transporter; $20 \mu \mathrm{l}$ vesicle protein was mixed with $20 \mu \mathrm{l}$ buffer C ( $240 \mathrm{mM}$ sucrose, 50 $\mathrm{mM}$ leucine, $5 \mathrm{mM}$ Hepes, $5 \mathrm{mM}$ Tris; titrated to $\mathrm{pH} 7.4$ with 11.6 $\mathrm{M} \mathrm{HCl}$ and to which $\left[\mathrm{L}-{ }^{14} \mathrm{C}\right]$ leucine was added so that the final radioactive leucine concentration was $20 \mu M$ ). The reaction was terminated at the intervals shown by adding $2 \mathrm{ml}$ of ice-cold KrebsRinger phosphate solution. $1 \mathrm{ml}$ was immediately filtered through presoaked millipore filters $(0.45 \mu \mathrm{m})$ and washed with $10 \mathrm{ml}$ of Krebs-Ringer phosphate solution. Values shown are mean $\pm S E$ for vesicle preparations from five to six placentas in the control group, four placentas in the AGA group, and four to five placentas in the FM group. $\sigma$ is total uptake data; $\Delta$ is uptake in the presence of excess unlabeled leucine.
Table IV. Initial and Equilibrium Uptakes of $\left[{ }^{14} \mathrm{C}\right]$ Leucine at $4^{\circ} \mathrm{C}$

\begin{tabular}{|c|c|c|c|c|c|}
\hline & \multicolumn{5}{|c|}{$\left[{ }^{14} \mathrm{C}\right]$ Leucine uptake $(\mathrm{pmol} / \mathrm{mg}$ protein) } \\
\hline & \multicolumn{3}{|c|}{$3 \mathrm{~s}$} & \multicolumn{2}{|c|}{$24 \mathrm{~h}$} \\
\hline & Total $*$ & $\begin{array}{l}\text { Excess } \\
\text { leucine }\end{array}$ & "L" & Total & $\begin{array}{l}\text { Excess } \\
\text { leucine }\end{array}$ \\
\hline $\mathrm{C}$ & $3.88 \pm 0.34$ & $0.26 \pm 0.13$ & $3.62 \pm 0.31$ & $41.9 \pm 8.2$ & $21.2 \pm 0.7$ \\
\hline AGA & $4.14 \pm 0.52$ & $0.30 \pm 0.13$ & $3.84 \pm 0.57$ & $48.9 \pm 20.7$ & $20.6 \pm 1.7$ \\
\hline FM & $5.12 \pm 1.07$ & $0.33 \pm 0.17$ & $4.79 \pm 1.12$ & $46.1 \pm 12.8$ & $23.6 \pm 2.3$ \\
\hline
\end{tabular}

Values are mean \pm SE. C, control, $n=6$; AGA, $n=4$; FM $n=5$.

* Total uptake of $\left[{ }^{14} \mathrm{C}\right]$ leucine; Excess leucine is the uptake of $\left[{ }^{14} \mathrm{C}\right]$ leucine in the presence of $50 \mathrm{mM}$ unlabeled leucine in the EVB, and " $L$ " is the difference between the two representing uptake by the system $\mathrm{L}$ transporter.

was $<2 \%$ for all three groups (Fig. 4). Uptake in the presence of amiloride was significantly lower than that in its absence at all time points up to $60 \mathrm{~min}$. Both total and amiloride-insensitive $\mathrm{Na}^{+}$uptakes were linear over the first minute. In addition, the amiloride-sensitive $\mathrm{Na}^{+}$uptake (calculated as the difference between that in the presence and absence of amiloride) was also linear over the first minute. For comparison purposes, therefore, the uptake at $30 \mathrm{~s}$ was taken to represent an initial rate. The initial and equilibrium uptakes are shown in Table V; there were no significant differences between any of the groups.

\section{Discussion}

This study provides the first report on placental MVM transporter activity in relation to fetal overgrowth and diabetes in women. System A transporter activity was significantly and markedly lower in the MVM from placentas of FM babies from diabetic pregnancies as compared with MVM of control pregnancies. The significantly lower $V_{\max }$ but not $K_{\mathrm{m}}$ of this transporter in the FM group as compared with the control group suggests that the number of transporters was reduced. Furthermore, the lack of difference in either system $\mathrm{L}$ or $\mathrm{Na}^{+} / \mathrm{H}^{+}$ exchanger activity between the three groups suggests that the effect on system $A$ is quite selective.

Less clear-cut is the effect of diabetes per se on system A activity. We failed to find a significant difference in system A transporter activity of MVM from placentas of AGA babies from diabetic pregnancies as compared with control or as compared with MVM from placentas of FM babies. Although this, together with a previous report that there is no change in the total uptake of aminoisobutyric acid by MVM from placentas of diabetic pregnancies with normal fetal growth as compared with normal pregnancies (11), suggests that reduced transporter activity may be primarily related to macrosomia rather than diabetes (especially as in the present study there was no difference in the glycemic control achieved in the two diabetic groups). Clarification of this point awaits study of placentas of macrosomic babies born to patients shown definitively not to have diabetes or impaired glucose tolerance during pregnancy.

The placentas in the FM group were of a slightly but significantly lower gestation than in the control group. Higher $\mathrm{Na}^{+}$-dependent uptake of $\mathrm{L}$-alanine by late gestation (37-38 wk) human placental MVM vesicles as compared with early gestation (12-13 wk) MVM vesicles has been described (26). 

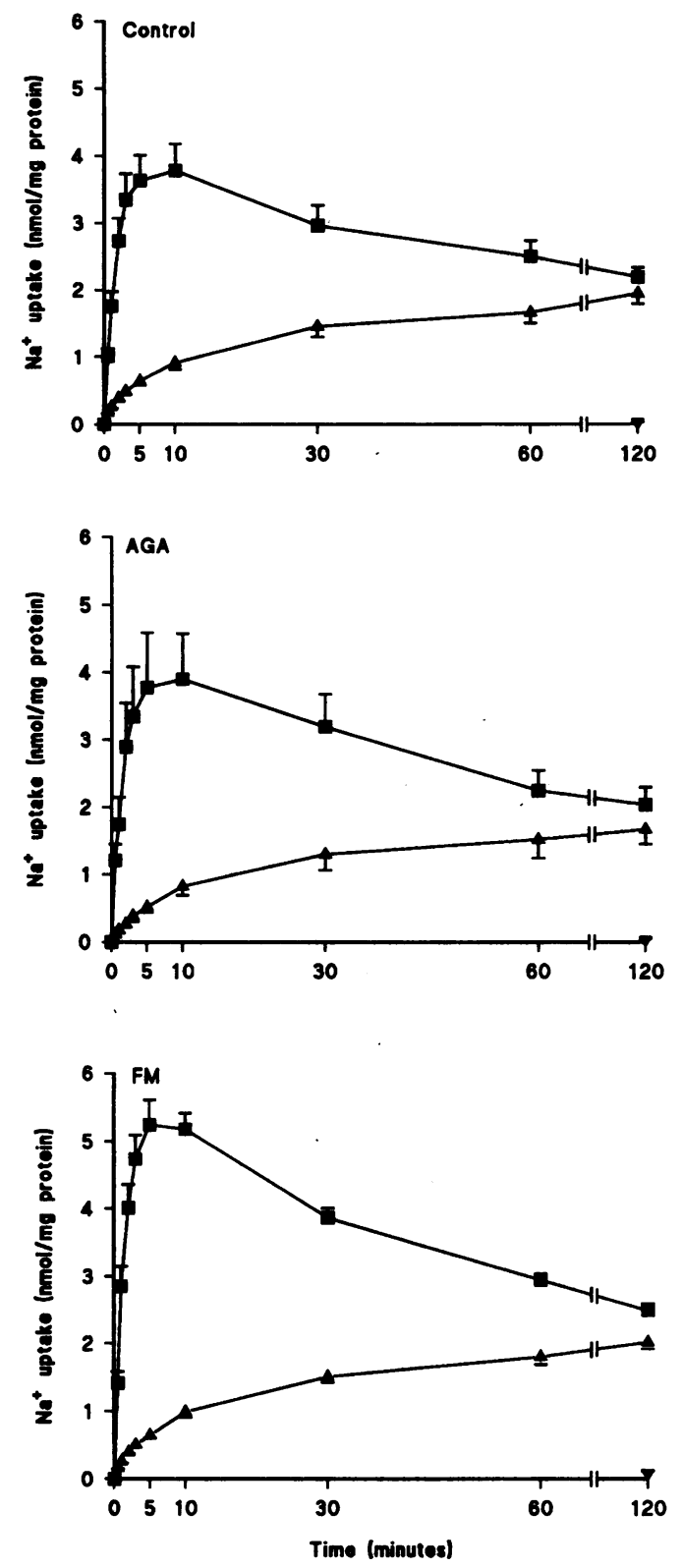

Figure 4. Time course of $\mathrm{Na}^{+}$uptake by control, AGA, and FM vesicles. Vesicles were suspended in buffer consisting of $25 \mathrm{mM}$ Mes, $5 \mathrm{mM}$ Tris, $149 \mathrm{mM} \mathrm{KCl}$, and $1 \mathrm{mM} \mathrm{NaCl}$ (pH 5.6) at a concentration of $\sim 15 \mathrm{mg} / \mathrm{ml}$. Uptake at room temperature was initiated by adding 200 $\mu \mathrm{l}$ of this suspension to $900 \mu \mathrm{l} \mathrm{EVB}$ consisting of $18 \mathrm{mM}$ Hepes, $12 \mathrm{mM}$ Tris, $149 \mathrm{mM} \mathrm{KCl}$, and $1 \mathrm{mM} \mathrm{NaCl}$ (pH 7.6) to which 2.5 $\mu \mathrm{Ci} / \mathrm{ml}$ sodium- 22 had been added, in the absence ( $\square$ ) and presence $(\Delta)$ of $0.5 \mathrm{mM}$ amiloride. Aliquots of $100 \mu \mathrm{l}$ of this mix were applied, at the intervals shown, to ion-exchange columns and washed with 2.5 $\mathrm{ml}$ of EVB. $\nabla$ represents uptake in the presence of $0.2 \%$ Triton. Values shown are mean $\pm \mathrm{SE}$ for vesicle preparations from 9 to 12 placentas in the control group, 7 to 8 placentas in the AGA group, and 6 to 10 placentas in the FM group. Error bars are not shown if less than the symbol size.

However, it seems unlikely that there would be a large increase in amino acid uptake in the last 3 wk of pregnancy. Indeed, we were unable to demonstrate any correlation in any of the three groups between the initial rates of uptake of $\left[{ }^{14} \mathrm{C}\right] \mathrm{MeAIB}$ and the period of gestation (data not shown; the range of the period
Table V. Initial and Equilibrium Uptakes of $\mathrm{Na}^{+}$by Vesicles

\begin{tabular}{|c|c|c|c|c|c|}
\hline & \multicolumn{5}{|c|}{$\mathrm{Na}^{+}$uptake (nmol/mg protein) } \\
\hline & \multicolumn{3}{|c|}{$30 \mathrm{~s}$} & \multicolumn{2}{|c|}{$2 \mathrm{~h}$} \\
\hline & Total* & $\begin{array}{l}\text { Amiloride } \\
(0.5 \mathrm{mM})\end{array}$ & $\begin{array}{l}\mathrm{Na}^{+} / \mathrm{H}^{+} \\
\text {exchanger }\end{array}$ & Total* & $\begin{array}{l}\text { Amiloride } \\
(0.5 \mathrm{mM})\end{array}$ \\
\hline $\mathrm{C}$ & $1.01 \pm 0.12$ & $0.17 \pm 0.01$ & $0.84 \pm 0.11$ & $2.20 \pm 0.14$ & $1.95 \pm 0.16$ \\
\hline AGA & $1.21 \pm 0.24$ & $0.12 \pm 0.03$ & $1.09 \pm 0.23$ & $2.04 \pm 0.26$ & $1.67 \pm 0.22$ \\
\hline FM & $1.42 \pm 0.17$ & $0.16 \pm 0.01$ & $1.25 \pm 0.16$ & $2.49 \pm 0.10$ & $2.02 \pm 0.10$ \\
\hline
\end{tabular}

Values are mean $\pm \mathrm{SE}$. C, control, $n=12$; AGA, $n=8$; FM, $n=10$. * Total uptake of $\mathrm{Na}^{+}$in the absence of amiloride; the uptake by the $\mathrm{Na}^{+} / \mathrm{H}^{+}$exchanger is calculated as the difference between the total uptake and the uptake in the presence of $0.5 \mathrm{mM}$ amiloride.

of gestation was $\sim 4$ wk.). We therefore believe that the lower system A activity in the FM group was not a result of gestational differences per se.

As system A activity is reduced in MVM from placentas of growth-retarded babies $(11,12)$, the finding here that it is similarly reduced in FM was somewhat surprising, although in streptozotocin-induced, mildly diabetic pregnant rats giving birth to macrosomic fetuses, fetal plasma amino acids have been shown to be reduced despite normal maternal concentrations (27).

For the physiological significance of our data on the system A transporter to be determined, a number of other factors need to be taken into consideration. Transcellular amino acid net flux across the placenta in vivo will be dependent on: $(a)$ the activities and numbers of transporters in both the microvillous and basal plasma membranes of the syncytiotrophoblast and the balance between maternofetal and fetomaternal flux; included in this will be the surface area of plasma membrane; $(b)$ maternal and fetal plasma concentrations of amino acids; the importance of this will be dependent on the $K_{\mathrm{m}}$ of transporters; (c) for $\mathrm{Na}^{+}$-dependent electrogenic transfer, as occurs with the system A transporter, membrane potential and any transplacental potential difference will be important (28); and (d) syncytiotrophoblast amino acid metabolism (29).

Our kinetic data suggest that the system A transporter is not saturated at physiological concentrations of its substrates. Therefore, raised maternal plasma concentrations as may occur in diabetes $(30,31)$ would be likely to increase flux of substrate via the transporter opposing its apparent downregulation. Furthermore, there is a hint that syncytiotrophoblast plasma membrane surface area is increased in diabetes (32). However, nothing is known about the electrophysiology of the human diabetic placenta or of its amino acid metabolism.

Therefore, we currently have insufficient information to establish whether in vivo substrate flux via the system A transporter in the MVM of the FM placenta in diabetes near term reflects its lower in vitro activity per milligram of membrane protein. However, it does seem more likely that the latter is an adaptation to macrosomia, rather than it being important in its genesis.

The placenta is rich in insulin receptors on the MVM (33). The effects of diabetes on placental insulin receptors have been variably reported as no change, decreased, and increased concentrations (34-36). The reports on insulin effects on placental amino acid transport are also conflicting with some reporting 
no change (37) and others demonstrating stimulation of uptake $(38,39)$. Therefore, it is not possible to determine the role of insulin in the changes in transporter activity which we have observed, although this does seem to be a likely mediator of the effect.

In conclusion, this investigation has demonstrated that placental MVM system A transporter activity is selectively reduced when diabetic pregnancy results in FM, probably due to a decrease in the number of transporters.

\section{Acknowledgments}

We are grateful to Professor Robert Boyd for his helpful suggestions throughout the course of this study.

This work was supported by a grant from the Medical Research Council.

\section{References}

1. Modanlou, H. D., W. L. Dorchester, A. Thorosian, and R. Freeman. 1980. Macrosomia-maternal, fetal and neonatal implications. Obstet. Gynecol. 55:420-424.

2. Boyd, M. E. 1984. Fetal macrosomia. In Progress in Obstetrics and Gynaecology. Volume 4. J. Studd, editor. Churchill Livingstone, Edinburgh. 118-126.

3. Stenninger, E., J. Schollin, and J. Åman. 1991. Neonatal macrosomia and hypoglycaemia in children of mothers with insulin-treated gestational diabetes mellitus. Acta Paediatr. Scand. 80:1014-1018.

4. Combs, C. A., E. G. Gunderson, J. L. Kitzmiller, L. A. Gavin, and E. K. Main. 1992. Relationship of fetal macrosomia to maternal postprandial glucose control during pregnancy. Diabetes Care. 15:1251-1257.

5. Berk, M. A., F. Mimouni, M. Miodovnik, V. Hertzberg, and J. Valuck. 1989. Macrosomia in infants of insulin-dependent diabetic mothers. Pediatrics. 83:1029-1034

6. Pedersen, J. 1954. Weight and length at birth of infants of diabetic mothers. Acta Endocrinol. 16:330-342.

7. Dandona, P., H. S. Besterman, D. B. Freedman, F. Boag, A. M. Taylor, and A. G. Beckett. 1984. Macrosomia despite well-controlled diabetic pregnancy. Lancet. i:737.

8. Freinkel, N. 1980. Of pregnancy and progeny. Diabetes. 29:1023-1035.

9. Carter, B. S., R. R. Moores, and F. C. Battaglia. 1991. Placental transport and fetal and placental metabolism of amino acids. J. Nutr. Biochem. 2:4-13.

10. Yudilevich, D. L., and J. H. Sweiry. 1985. Transport of amino acids in the placenta. Biochim. Biophys. Acta. 822:169-201.

11. Dicke, J. M., and G. I. Henderson. 1988. Placental amino acid uptake in normal and complicated pregnancies. Am. J. Med. Sci. 295:223-227.

12. Mahendran, D., P. Donnai, J. D. Glazier, S. W. D'Souza, R. D. H. Boyd, and C. P. Sibley. 1993. Amino acid (system A) transporter activity in microvillous membrane vesicles from the placentas of appropriate and small for gestational age babies. Pediatr. Res. 34:661-665.

13. Kulanthaivel, P., T. C. Furesz, A. J. Moe, C. H. Smith, V. B. Mahesh, F. H. Leibach, and V. Ganapathy. 1992. Human placental syncytiotrophoblast expresses two pharmacologically distinguishable types of $\mathrm{Na}^{+}-\mathrm{H}^{+}$exchangers, NHE-1 in the maternal-facing (brush border) membrane and NHE-2 in the fetalfacing (basal) membrane. Biochem. J. 284:33-38.

14. Gairdner, D., and J. Pearson. 1971. A growth chart for premature and other infants. Arch. Dis. Child. 46:783-787.

15. Hare, J. W., and P. White. 1980. Gestational diabetes and the White classification. Diabetes Care. 3:394.

16. WHO Expert Committee on Diabetes Mellitus. Second Report. Geneva. World Health Organization Technical Report Series 646. 10-13.
17. Glazier, J. D., C. J. P. Jones, and C. P. Sibley. 1988. Purification and $\mathrm{Na}^{+}$ uptake by human placental microvillus membrane vesicles prepared by three different methods. Biochim. Biophys. Acta. 945:127-134.

18. Lowry, O. H., N. J. Rosebrough, A. L. Farr, and R. J. Randall. 1951. Protein measurement with the Folin phenol reagent. J. Biol. Chem. 193:265-275.

19. Jones, C. J. P., and H. Fox. 1991. Ultrastructure of the normal human placenta. Electron Microsc. Rev. 4:129-178.

20. McComb, R. B., and G. N. Bowers, Jr. 1972. Study of optimum buffer conditions for measuring alkaline phosphatase in human serum. Clin. Chem. 18:97-104.

21. Fleisher, S., G. Brierly, H. Klouwen, and D. B. Slautterback. 1962. Studies of the electron transfer system XLVII. The role of phospholipids in electron transfer. J. Biol. Chem. 237:3264-3272.

22. Sottocasa, G. L., B. Kuylenstierna, L. Ernster, and A. Bergstrand. 1967. An electron-transport system associated with the outer membrane of liver mitochondria. A biochemical and morphological study. J. Cell Biol. 32:415-438.

23. Kudo, Y., K. Yamada, A. Fujiwara, and T. Kawasaki. 1987. Characterisation of amino acid transport systems in human placental brush-border membrane vesicles. Biochim. Biophys. Acta. 1021:169-174.

24. Johnson, L. W., and C. H. Smith. 1988. Neutral amino acid transport systems of microvillous membrane of human placenta. Am. J. Physiol. 254:C773C780.

25. Gasko, O. D., A. F. Knowles, H. G. Shertzer, E.-M. Suolinna, and E. Racker. 1976. The use of ion-exchange resins for studying ion transport in biological systems. Anal. Biochem. 72:57-65.

26. Ioka, H., H. Hisanaga, I. S. Moriyama, S. Akada, T. Shimamoto, Y. Yamada, and M. Ichijo. 1992. Characterization of human placental activity for transport of L-alanine, using brush border (microvillous) membrane vesicles. Placenta. 13:179-190.

27. Aerts, L., R. Van Bree, V. Feytons, W. Rombauts, and F. A. Van Assche 1989. Plasma amino acids in diabetic pregnant rats and in their fetal and adult offspring. Biol. Neonate. 56:31-39.

28. Greenwood, S. L., R. D. H. Boyd, and C. P. Sibley. 1993. Transtrophoblast and microvillus membrane potential difference in mature intermediate human placental villi. Am. J. Physiol. 265:C460-C466.

29. Carroll, M. J., and M. Young. 1983. The relationship between placental protein synthesis and transfer of amino acids. Biochem. J. 210:99-105.

30. Potter, J. M., A. Green, D. R. Cullen, and R. D. G. Milner. 1986. Amino acid profiles in early diabetic and non-diabetic pregnancy. Diabetes Res. Clin. Pract. 2:123-126.

31. Kalkhoff, R. K., E. Kandaraki, P. G. Morrow, T. H. Mitchell, S. Kelber, and H. I. Borkowf. 1988. Relationship between neonatal birth weight and maternal plasma amino acid profiles in lean and obese nondiabetic women and in type I diabetic pregnant women. Metab. Clin. Exp. 37:234-239.

32. Teasdale, F. 1985 . Histomorphometry of the human placenta in class C diabetes mellitus. Placenta. 6:69-82.

33. Whitsett, J. A., C. L. Johnson, and K. Hawkins. 1979. Differences in localization of insulin receptors and adenylate cyclase in the human placenta. Am. J. Obstet. Gynecol. 133:204-207.

34. Harrison, L. C., T. Billington, S. Clark, R. Nichols, I. East, and F. I. R. Martin. 1977. Decreased binding of insulin by receptors on placental membranes from diabetic mothers. J. Clin. Endocrinol. \& Metab. 44:206-209.

35. Durán-Garcia, S., J. G. Nieto, and A. M. Cabello. 1979. Effect of gestational diabetes on insulin receptors in human placenta. Diabetologia 16:87-91.

36. Desoye, G., H. H. Hofmann, and P. A. M. Weiss. 1992. Insulin binding to trophoblast plasma membranes and placental glycogen content in well-controlled gestational diabetic women treated with diet or insulin, in well-controlled overt diabetic patients and in healthy control subjects. Diabetologia. 35:45-55.

37. Steel, R. B., J. D. Mosley, and C. H. Smith. 1979. Insulin and placenta: degradation and stabilization, binding to microvillous membrane receptors, and amino acid uptake. Am. J. Obstet. Gynecol. 135:522-529.

38. Dancis, J., W. L. Money, D. Springer, and M. Levitz. 1968. Transport of amino acids by placenta. Am. J. Obstet. Gynecol. 101:820-829.

39. Karl, P. I., K. L. Alpy, and S. E. Fisher. 1992. Amino acid transport by the cultured human placental trophoblast: effect of insulin on AIB transport. Am. J. Physiol. 262:C834-C839. 